\title{
The Effects of Financial Literacy and Self-Control towards Financial Behavior among High School Students in Bogor
}

\author{
Jihaan Khoirunnisaa ${ }^{1}$, Irni Rahmayani Johan ${ }^{* 2}$ \\ ${ }^{1}$ Department of Family and Consumer Science, Faculty of Human Ecology, IPB \\ University, Bogor 16680, West Java, Indonesia \\ ${ }^{2}$ Department of Family and Consumer Science, Faculty of Human Ecology, IPB \\ University, Bogor 16680, West Java, Indonesia \\ *Corresponding author: irni_johan@apps.ipb.ac.id
}

\begin{abstract}
This research aims to analyze the effect of financial literacy and self-control on financial behavior among Bogor High School students. This research was conducted in two public high schools in Bogor, West Java, Indonesia, that were selected based on the level of passing grade of the school (high-grade and low grade). In collecting the data, this study used a self-administered questionnaire. About 113 of senior high school students from science and social majors were selected as the sample. This study found that financial knowledge and financial attitude were on a moderate level. High-grade school students tend to have better financial knowledge and attitude than those from low-grade schools. The results of this study also show that the self-control of students was classified as a low category. Those from low-grade schools were more likely to have better self-control compared to students from the high-grade school. Furthermore, financial behavior, which consists of saving and spending behavior, were categorized as poor. There was a significant difference in financial knowledge, financial attitude, and self-control among both schools. The financial attitude was positively significantly related to financial knowledge and behavior. Self-control was associated positively with financial behavior. Further analysis of multiple linear regression shows a positive and significant effect of financial attitude and self-control towards financial behavior.
\end{abstract}

Keyword: financial attitude, financial knowledge, financial behavior, high school student, self-control

\begin{abstract}
Abstrak
Penelitian ini bertujuan untuk menganalisis pengaruh literasi keuangan dan pengendalian diri terhadap perilaku keuangan pada siswa SMA Bogor. Penelitian ini dilakukan di dua SMA Negeri di Bogor, Jawa Barat, Indonesia, yang dipilih berdasarkan tingkat kelulusan sekolah (kelas tinggi dan kelas rendah). Sebanyak 113 siswa SMA dari jurusan IPA dan IPS terlibat sebagai responden dalam penelitian ini. Data primer dikumpulkan dengan menggunakan kuesioner yang diisi mandiri oleh responden. Studi ini menemukan bahwa pengetahuan keuangan dan sikap keuangan
\end{abstract}


berada pada kategori sedang. Siswa sekolah dasar cenderung memiliki pengetahuan dan sikap keuangan yang lebih baik daripada siswa sekolah dasar yang rendah. Hasil penelitian ini juga menunjukkan bahwa pengendalian diri siswa termasuk dalam kategori rendah. Siswa dari sekolah dasar lebih cenderung memiliki pengendalian diri yang lebih baik dibandingkan dengan siswa dari sekolah menengah atas. Perilaku keuangan yang terdiri dari perilaku menabung dan berbelanja dikategorikan buruk. Ada perbedaan yang signifikan pada pengetahuan keuangan, sikap keuangan dan pengendalian diri antara kedua sekolah. Sikap keuangan berhubungan positif signifikan dengan pengetahuan dan perilaku keuangan. Pengendalian diri dikaitkan secara positif dengan perilaku keuangan. Hasil analisis regresi linier berganda menunjukkan sikap keuangan, dan pengendalian diri berpengaruh positif dan signifikan terhadap perilaku keuangan.

Kata kunci: pengetahuan keuangan, perilaku keuangan, pengendalian diri, sikap keuangan, siswa SMA.

\section{Introduction}

The world is getting more connected in all aspect that makes changes in global economic trends including in term of finance, and it might affect individual financial security (Policy Research Initiative [PRI], 2005). In line with this, people's ability to manage their finances become more important. Those with good financial management are more likely to be financially secured and more able to face any changes in the future (PRI, 2005). Financial management tends to be associated with financial behavior. Good financial behaviors are demonstrated by various activities, including good financial planning, managing, and controlling (Laily, 2013). Not only is it important for adults, financial behavior is also crucial for adolescents as behavior patterns developed in adolescence will be the basis for financial behavior and well-being later in life (Beverly \& Burkhalter, 2005).

Adolescence is a transitional period from childhood to adulthood that occurs between ages 10 and 19 (UNICEF, 2011). During this period, adolescents develop independent thoughts and actions from their parents. High school students (late adolescents) face various choices of financial products and services such as savings (Kim \& Chatterjee, 2013; Organisation for Economic Cooperation and Development [OECD], 2017). According to OECD (2017) stated that at the end of primary education level, adolescents need to make major decisions regarding their future, such as deciding between going to college or get some work experience. However, adolescents are considered to be the most consumptive than any other age group (Fitriani, Widodo, \& Fauziah, 2013; Kanserina, 2015). In other words, adolescents are less likely to show positive and healthy financial behavior by using the money to fulfill their desires over their needs. The study of Nurasiyah, Dahlan, and Budiwati (as cited in Ardiana, 2016) towards high school students in Bandung shows that students spend more money on the fun $(21.26 \%)$ than educational-related needs as a long-term investment, even save less than two percent of monthly income.

Money management is associated with financial literacy (Laily, 2013). Financial literacy is defined as the understanding of financial concept and products, as well as the attitude toward money to make appropriate financial decisions related to budgeting, 
borrowing, saving, and investing (Atkinson \& Messy, 2012; Gaurav \& Singh, 2012; Huston, 2010; PRI, 2005; Setiawati \& Nurkhin, 2017; Xiao, 2008). Lack of financial literacy leads to poor financial behavior, including debt behavior (Lusardi \& Tufano, 2009; Zahirovic-Herbert, Gibler, \& Chatterjee, 2016). Unfortunately, the results of the survey conducted by Otoritas Jasa Keuangan [OJK] (2016) shows that the national financial literacy index is around 29.66 percent, meanwhile financial literacy index of West Java Province was 38.70 percent. A ratio of 29 to a total of 100 Indonesian citizens and only 38 out of 100 citizens of West Java have a high level of financial literacy. For adolescents aged 15 to 17 years, the index for conventional and sharia financial literacy was around 5.2 percent and 2.2 percent each.

Self-control is an ability to regulate impulsive buying patterns to achieve financial goals (Baumeister, 2002; Otto, Davies, \& Chater, 2007). Self-control is linked to better general financial behavior. Adolescents with low self-control are relatively more vulnerable to risky financial behavior (Weaver, Moschis, \& Davis, 2011). Cognitive ability is considered an important factor affecting individual financial literacy and selfcontrol. Individuals with a higher level of cognitive ability tend to have a greater capacity to understand financial concepts and self-controlling better (Hastings, Madrian, \& Skimmyhorn, 2013; Luhrmann, Serra-Garcia, \& Winter, 2014).

Based on data related to financial literacy, self-control, and financial behavior as described above, thus this study aims to: 1) identify characteristics of samples, characteristics of schools, level of financial literacy, self-control, and financial behavior of Bogor High School students; 2) differentiate the level of financial literacy, self- control, financial behavior of Bogor High School students based on the passing grade of the school; 3) analyze the association between characteristics of samples, characteristics of schools, financial literacy, self-control, and financial behavior of Bogor High School students; 4) analyze the effect of characteristics of samples, characteristics of schools, financial literacy, and self-control towards financial behavior of Bogor High School students.

\section{Methods}

\section{Participant}

In this study, the location of the research and sample were selected purposively. This study was held in two public high schools in Bogor, West Java, Indonesia. The reason for selecting this location was based on OJK (2016) that showed that the financial literacy index of West Java Province was categorized as less literate. Public high school was chosen due to the socio-economic diversity of its students that represented by monthly pocket money (Sinaga, 2017). Public high school with high and low passing grade score of 2018/2019 school year were then selected, each category was represented by one school.

The sample in both schools was then selected based on the major of the course, which is science and social major. This is in line with Opoku (2015), who explained that there is a relationship between economic education and financial knowledge. Students from social majors were predicted to have higher financial knowledge through related subjects such as economics and accountancy. In addition, another requirement of the sample was those who lived in a complete family. The total sample in this study was 113 students, comprised of 60 students from high passing grade school (33 major 
science students vs. 27 major social students), and 53 students from low passing grade school (29 science major students vs. 24 major social students).

\section{Data Collection}

The primary data was collected during April 2019 through a self-administered questionnaire. The questionnaire comprised four main parts that are personal and family characteristics (e.g., age, gender, residence, income, education, etc.), financial literacy (knowledge and attitudes), self-control, and financial behavior. Each respondent was asked to complete the questionnaire independently without interacting with each other.

\section{Measures}

In this study, financial literacy consisted of financial knowledge and attitude. Financial knowledge was defined as the understanding of the general financial concept in everyday life, including inflation, discount, and interest rates. The instrument of financial knowledge was a modified version of Atkinson and Messy (2012) questionnaire comprised of five questions with multiple choice answer types (nominal scale). Each correct answer was scored as "1" and "0" for the incorrect answer. In addition, the financial attitude was measured using an adapted and modified version of Amagir, Groot, van den Brink, and Wilschut (2017) with Cronbach's alpha 0.664. The questionnaire consisted of four dimensions ranging from power/prestige (money as a symbol of success and power), financial planning (importance of budgeting and planning), think before acting (ability to analyze each alternative carefully), and quality for the money (spending money on high-quality products).

Self-control was referred to as a modified version of a brief self-control questionnaire by Tangney (2004) in OECD (2017) (Cronbach's alpha 0.779). The instrument was divided into five dimensions which are self-discipline (ability to discipline oneself), non-impulsive (tendency to consider all alternatives carefully), work ethic (ability to rate self-regulation at work), healthy habit (ability to adjust and break the bad habits), reliability (self-assessment regarding the ability to achieve long-term goals). Financial attitude and self-control variables were measured on four points Likert scale, ranging from "1" (strongly disagree) to "4" (strongly agree). Furthermore, the financial behavior variable was measured using the modified version of Opoku (2015) questionnaire with eight particular statements related to saving and spending behavior (Cronbach's alpha 0.738). Each statement was scored on five-point Likert scale from "1" (never), "2" (rarely), "3" (sometimes), "4" (often), and "5" (very often).

\section{Analysis}

The data was then processed and analyzed using Microsoft Office Excel and IBM Statistical Package for Social Science (SPSS) Statistics. The data analysis method used descriptive and inferential statistics. For financial knowledge and behavior, the cut-off point was based on Chen and Volpe $(1998)$ that is, low/poor $(<60.0)$, moderate $(60.0$ 79.9 ), high/good ( $\geq 80.0$ ). The cut-off point of financial attitude was referred to Rajha (2011), which is poor $(<60.0)$, moderate (60.0-80), good (>80.0). Meanwhile, the cut-off point for the self-control variable was based on Farhatilwardah, Hastuti, \& Krisnatuti (2019), which is low (<60.0); moderate (60.0-80.0); and high $(>80.0)$. 


\section{Findings}

\section{Characteristics of Sample}

All samples were in the late adolescence phase, with the largest proportion of students aged 16 years old. The sample was dominated by female students. Around 55.5 percent were students from the high-grade school. More than half of the students were from science majors, while the rest were from social majors. The amounts of pocket money were varied. However, the majority of the students received the allowance between IDR 200.001 and IDR 1.000000 each month, with the average amount was around IDR 572.740 each month.

The majority of students' parents in both schools were classified in middle adulthood, with ages ranging from 41 to 60 years old. The average age of fathers was 49.8 years old, while mothers were 45.9 years old. The percentage of fathers that had attained a bachelor's degree was 43.3 percent for high-grade school, while for the lowgrade school, the highest percentage of fathers' education was high school (45.3\%). About a third of mothers of high-grade school students earned a diploma degree, and the majority of mothers of low-grade school students had completed high school. In term of occupation, the highest proportion of fathers of high-grade school students worked as a private employee or civil servants, that is around 48.3 percent, and about a third of father of low-grade school students worked as an entrepreneur. Three-quarters of mothers of all samples were housewives. Four often of high-grade school students had family income ranged from IDR 5.000001 to 10.000000 each month and was categorized as middle level. In addition, the family income of low-grade school students was categorized as low (less than IDR 5.000000 each month).

\section{Financial Literacy}

In this study, financial literacy is covered by financial knowledge and attitude. Overall, students have familiarity with the basic concept of finance, such as a discount, inflation, and interest rate. However, students' understanding of the time value of money and the compound interest rate was still low.

Table 1 Sample distribution by financial literacy index and school passing grade score

\begin{tabular}{|c|c|c|c|c|c|c|c|c|}
\hline \multirow{3}{*}{ Category } & \multicolumn{4}{|c|}{ High-Grade School } & \multicolumn{4}{|c|}{ Low-Grade School } \\
\hline & \multicolumn{2}{|c|}{ Science } & \multicolumn{2}{|c|}{ Social } & \multicolumn{2}{|c|}{ Science } & \multicolumn{2}{|c|}{ Social } \\
\hline & $\mathrm{n}$ & $\%$ & $\mathrm{n}$ & $\%$ & $\mathrm{n}$ & $\%$ & $\mathrm{n}$ & $\%$ \\
\hline \multicolumn{9}{|l|}{ Financial Knowledge } \\
\hline Low $(<60.0)$ & 4 & 12.1 & 3 & 11.1 & 6 & 20.7 & 12 & 50.0 \\
\hline Moderate (60.0-79.9) & 12 & 36.4 & 7 & 25.9 & 13 & 44.8 & 10 & 41.7 \\
\hline $\operatorname{High}(\geq 80.0)$ & 17 & 51.5 & 17 & 63.0 & $1 C$ & 34.5 & 2 & 8.3 \\
\hline Min-Max & \multicolumn{4}{|c|}{$0-100$} & \multicolumn{4}{|c|}{$0-100$} \\
\hline Mean \pm SD & \multicolumn{4}{|c|}{$71.33 \pm 22.5$} & \multirow{2}{*}{\multicolumn{4}{|c|}{$56.60 \pm 21.0$}} \\
\hline$P$-value & \multirow{2}{*}{\multicolumn{8}{|c|}{$0.001 * *$}} \\
\hline Financial Attitude & & & & & & & & \\
\hline Poor $(\leq 33.3)$ & 0 & 0.0 & 0 & 0.0 & 0 & 0.0 & 0 & 0.0 \\
\hline Moderate (33.4-66.6) & 3 & 9.1 & 4 & 14.8 & 12 & 42.8 & 13 & 59.1 \\
\hline Good $(>66.6)$ & 30 & 90.9 & 23 & 85.2 & 16 & 57.2 & 9 & 40.9 \\
\hline Min-Max & \multicolumn{4}{|c|}{$60.9-89.9$} & \multicolumn{4}{|c|}{$56.5-89.9$} \\
\hline Mean \pm SD & \multicolumn{4}{|c|}{$73.9 \pm 6.5$} & \multirow{2}{*}{\multicolumn{4}{|c|}{$69.2 \pm 87$}} \\
\hline$P$-value & & & & & & & & \\
\hline
\end{tabular}


Table 1 shows that a significant difference was found between students of schoolbased on passing grade scores. Overall. Financial knowledge of students from high-grade schools was classified as a moderate level (mean score $=71.3$ ), while students from the low-grade school were more likely to have a low level of financial knowledge (mean score=56.6). The results show that more than half of students in high-grade schools recorded a high level of financial knowledge. On the other hand, only two out of ten students from the low-grade school had a high level of financial knowledge, with students from science major were more likely to understand the concept related to financial better than students in social major.

In terms of attitude, the majority of students from high-grade schools recorded to have a good financial attitude. It indicates that the majority of the students held a positive attitude towards financial activity, such as saving. Meanwhile lower percentage was found among students in the low-grade school (Table 1). This study then found a significant difference between students in both schools based on the passing grade score. The average score of high-grade school students (mean score $=73.9$ ) is found to be higher than the low-grade school (mean score= 69.2). However, this study found that students from science majors in both schools documented better attitudes than those from the social major.

\section{Self-Control}

The result of this study shows that the majority of students have a poor level of self-control, with a maximum and minimum score of around 69 and 22 (Table 2). About 60 percent of high-grade school students reported to have problems in breaking the bad habits, and half of the students were more likely to use inappropriate words. Just over half of the students were able to be a self-disciplined, such as doing activities as scheduled and submitting homework on time. However, the majority of students admitted that they are not seen as a self-disciplined person by other people. It indicates that there is a gap between other perceptions and individual self-perception.

Table 2 Sample distribution by self-control index and school passing grade score

\begin{tabular}{|c|c|c|c|c|c|c|c|c|}
\hline \multirow{3}{*}{ Category } & \multicolumn{4}{|c|}{ High-grade School } & \multicolumn{4}{|c|}{ Low-Grade School } \\
\hline & \multicolumn{2}{|c|}{ Science } & \multicolumn{2}{|c|}{ Social } & \multicolumn{2}{|c|}{ Science } & \multicolumn{2}{|c|}{ Social } \\
\hline & $\mathrm{n}$ & $\%$ & $\mathrm{n}$ & $\%$ & $\mathrm{n}$ & $\%$ & $\mathrm{n}$ & $\%$ \\
\hline Low $(<60.0)$ & 31 & 93.9 & 25 & 92.6 & 26 & 89.7 & 23 & 95.8 \\
\hline Moderate (60.0-80.0) & 2 & 6.1 & 2 & 7.4 & 3 & 10.3 & 1 & 4.2 \\
\hline $\operatorname{High}(>80.0)$ & 0 & 0.0 & 0 & 0.0 & 0 & 0.0 & 0 & 0.0 \\
\hline Min-Max & \multicolumn{4}{|c|}{$22.2-66.7$} & \multicolumn{4}{|c|}{$26.7-68.9$} \\
\hline Mean \pm SD & \multicolumn{4}{|c|}{$42.9 \pm 9.5$} & \multirow{2}{*}{\multicolumn{4}{|c|}{$47.0 \pm 9.4$}} \\
\hline$P$-value & & & & & & & & \\
\hline
\end{tabular}

Note: * significant at $\mathrm{p}<0.05$

In terms of the non-impulsive dimension, about $82.3 \%$ of the students have thought of all possible alternatives before making a decision. However, six out of ten students were unable to stop making bad habits, such as checking their phones while in the class. In terms of work ethic dimension, more than half of students (57.5\%) admitted to be lazy and procrastinate because prioritizing the pleasure and fun activities (55.8\%), and more than four in ten have problems concentrating. However, seven out of ten students have worked effectively to achieve their goals.

Students from the low-grade school were more likely to score 4.1 points higher than those from high-grade school. Interesting findings in this study, the low-grade 
school students were found to be more diligent, easier to get rid of bad habits and have a greater ability to resist temptation than high-grade school students. Moreover, students from social major were reported to have greater ability in controlling their self than those in a science major.

\section{Financial Behavior}

The financial behavior of students was categorized as poor. Although in attitudes dimension, more than half of students agreed to save money for the future $(54.9 \%)$ and before purchasing things (63.7\%), however in practice, around 38 percent of students from both school said only sometimes set aside money for savings and needs in the future (Table 3).

Table 3 Sample distribution by financial behavior index and school passing grade score

\begin{tabular}{|c|c|c|c|c|c|c|c|c|}
\hline \multirow{3}{*}{ Category } & \multicolumn{4}{|c|}{ High-grade School } & \multicolumn{4}{|c|}{ Low-Grade School } \\
\hline & \multicolumn{2}{|c|}{ Science } & \multicolumn{2}{|c|}{ Social } & \multicolumn{2}{|c|}{ Science } & \multicolumn{2}{|c|}{ Social } \\
\hline & $\mathrm{n}$ & $\%$ & $\mathrm{n}$ & $\%$ & $\mathrm{n}$ & $\%$ & $\mathrm{n}$ & $\%$ \\
\hline Poor $(<60.0)$ & 26 & 78.8 & 18 & 66.7 & 23 & 79.3 & 18 & 75.0 \\
\hline Moderate (60.0-79.9) & 0 & 0.0 & 0 & 0.0 & 0 & 0.0 & 0 & 0.0 \\
\hline Good $(\geq 80.0)$ & 7 & 21.2 & 9 & 33.3 & 6 & 20.7 & 6 & 25.0 \\
\hline Min-Max & & & 0.0 & & & & & \\
\hline Mean \pm SD & & & & & & & & \\
\hline$P$-value & & & & & & & & \\
\hline
\end{tabular}

Four out of ten students always compare prices before purchasing a product. Only 8.8 percent of the students said always spend time to do the budget. About 38.9 percent of students said they sometimes track their monthly income and expenses. Four out of ten students set aside money for an emergency fund. More than a third of students admitted to run out of money by the middle of the month. However, the same percentage of students recorded to have leftover money at the end of the month.

Based on the passing grade of schools, more than half of high-grade school students and four in ten of low-grade school students were classified as poor in terms of financial behavior. This study found no significant difference between students of both low and high-grade schools $(p$-value $=0.613)$. Students from social majors from both schools were more likely to have better financial behavior compare to those from science majors.

\section{Relationship between Sample Characteristics, Financial Knowledge, Financial Attitude, Self-Control, and Financial Behavior}

The result of the correlation test between variables recorded that financial attitude and self-control were positively associated with financial behavior (correlation coefficient $=0.34$ and $0.307, \mathrm{p}<0.05$ ). It indicates that the more positive financial attitude, the better of financial behavior. As the data states in Table 4, a significant negative correlation was found between the major of the course and financial knowledge with the coefficient correlation of -0.207 . Higher financial knowledge was more likely to be found among students from the science major. This study also revealed that financial knowledge was positively associated with financial attitude. Furthermore, a significant negative correlation was found between school passing grade score and financial literacy (both knowledge and attitude), while a positive relationship 
was found on self-control. This study also found that major, of course, were positively associated to the self-control.

Table 4 Correlation coefficient for sample characteristic, financial knowledge, financial attitude, self-control, and financial behavior

\begin{tabular}{lcccc}
\hline Variables & $\begin{array}{c}\text { Financial } \\
\text { Knowledge }\end{array}$ & $\begin{array}{c}\text { Financial } \\
\text { Attitude }\end{array}$ & Self-Control & $\begin{array}{c}\text { Financial } \\
\text { Behavior }\end{array}$ \\
\hline Age & -0.007 & 0.130 & 0.061 & 0.155 \\
Gender & -0.022 & -0.116 & -0.041 & 0.056 \\
Major of course & $\mathbf{- 0 . 2 0 7}^{*}$ & -0.140 & $\mathbf{0 . 2 9 3} * *$ & 0.064 \\
Pocket money & $\mathbf{- 0 . 2 2 6}^{*}$ & -0.007 & 0.054 & -0.037 \\
School passing grade score & $\mathbf{- 0 . 3 2 2}^{* *}$ & $\mathbf{- 0 . 2 9 9 * *}$ & $\mathbf{0 . 2 1 0 *}$ & -0.048 \\
Financial knowledge & 1 & $\mathbf{0 . 2 2 9 *}$ & -0.091 & -0.093 \\
Financial attitude & $\mathbf{0 . 2 2 9 *}$ & 1 & 0.095 & $\mathbf{0 . 3 4 0 * *}$ \\
Self-control & -0.091 & 0.095 & 1 & $\mathbf{0 . 3 0 7 *}$ \\
\hline
\end{tabular}

Note: *Significant at 0.05 level ; **Significant at 0.01 level

The Effects of Sample Characteristics, Financial Knowledge, Financial Attitude, and Self-Control towards Financial Behavior

The regression model examined the effects of sample characteristics, financial knowledge, and attitude, as well as self-control on financial behavior (Table 5). The results of the regression test showed that sample characteristics (age, gender, major of course, school passing grade score, pocket money) had no influence on students' financial behavior.

Table 5 Regression coefficient of sample characteristics, financial knowledge, financial attitude, and self-control on financial behavior

\begin{tabular}{|c|c|c|c|}
\hline Variables & $\begin{array}{l}\text { Non-standardized } \\
\text { coefficients }\end{array}$ & $\begin{array}{l}\text { Standardized } \\
\text { coefficients }\end{array}$ & Sig \\
\hline (Constant) & -30.905 & & 0.433 \\
\hline \multicolumn{4}{|l|}{ Sample Characteristics } \\
\hline Age (Years) & 2.152 & 0.080 & 0.365 \\
\hline $\begin{array}{l}\text { Gender } \\
(0=\text { Male, } 1=\text { Female })\end{array}$ & 3.179 & 0.102 & 0.254 \\
\hline $\begin{array}{l}\text { Major of course } \\
(0=\text { Science, } 1=\text { Social })\end{array}$ & 0.207 & 0.007 & 0.943 \\
\hline Pocket Money (IDR) & 0.001 & 0.014 & 0.875 \\
\hline \multicolumn{4}{|l|}{ School Characteristics } \\
\hline $\begin{array}{l}\text { School passing grade score } \\
(0=\text { high-grade school } \\
1=\text { low grade school })\end{array}$ & -1.869 & -0.063 & 0.522 \\
\hline \multicolumn{4}{|l|}{ Financial Literacy } \\
\hline Financial Knowledge (Index) & -0.106 & -0.165 & 0.093 \\
\hline Financial Attitude (Index) & 0.629 & 0.336 & $0.001 * *$ \\
\hline Self-Control (Index) & 0.418 & 0.271 & $0.005 * *$ \\
\hline $\mathrm{F}$ & & 3.968 & \\
\hline Adjusted R Square & & 0.175 & \\
\hline Sig. & & 0.000 & \\
\hline
\end{tabular}

Table 5 shows that there was a significant positive effect of financial attitude towards financial behavior $(\mathrm{B}=0.629)$. It means, for a single unit increase in financial attitude, the possibility of having better financial behavior would increase by 0.629 times. This study also revealed that the self-control variable was a determinant factor of 
financial behavior, where it showed a significant positive effect on financial behavior $\left(\mathrm{B}=0.418 ; \mathrm{p}=0.005^{* *}\right)$. An unexpected finding was found in terms of financial knowledge, where it was found to have no impact on financial behavior.

The model of regression of this study has adjusted $\mathrm{R}^{2}$ value around 0.175 . It indicates that sample characteristics, financial knowledge, financial attitude, and selfcontrol of this study could explain financial behavior of public high school students around 17.5 percent, while the rest $(82.5 \%)$ might be explained by another variable that was not observed in this research, such as motivation, lifestyle, financial socialization by parents, and the influence of peer group.

\section{Discussions}

Financial literacy is believed to have an important role so that individuals can make informed financial decisions (OECD, 2017). This study found that the level of financial literacy of students was in the moderate category. Only 18 percent of total students that recorded a sound financial literacy. This finding is supported by OJK (2019) where it was found that the younger group were more likely to be less literate in financial matter.

Students from high-grade schools were more likely to be more financially literate than those from low-grade school. This finding is in line with the study conducted by Lusardi, Mitchell, and Curto (2009), where it found that cognitive ability was one of the predictor factors of financial literacy. Students with better cognitive ability are more likely to have a high level of financial literacy. Financial education in school has a role in enhancing the level of students' financial literacy. With the assumption that students from social majors have received more financial-related subjects, it is predicted that they will be more likely to record a higher level of financial literacy (Amagir et al., 2017). However, a contrary result was found in this study, wherein general, students from science majors have documented a higher level of financial literacy than social majors.

There is a significant difference between students based on school passing grade score. High-grade school students seemed to have a better understanding of financial concepts compare to low-grade school. In addition, students from science majors, from both low and high-grade schools, were able to respond correctly toward questions of financial knowledge, particularly on the topic related to discount, inflation, and interest rate. This is allegedly caused by greater mathematical ability. Financial knowledge is not only about the understanding of finance, but also the basic numeracy concept (mathematical concept) inside of it. Thus, having basic mathematical ability will help the individual to understand the finance concept better (Yeboah, 2018). The study of Hastings et al. (2013) also states that individuals with a higher level of cognitive ability will understand the financial concept better, and it will increase the level of financial literacy.

The study conducted by Opoku (2015) found that an individual who has received financial and economic-related subjects will have a greater ability to understand financial knowledge than those who have not. However, the correlation test results in this study showed a significant negative correlation between the major of the course and financial knowledge. A higher level of financial knowledge was found among students from a science major. This result in lines with Mandell (2008), who argued that individuals taking financial-related subjects has not always financially 
literate. This may happen as students do not realize the importance of subjects they are taking for the future.

Financial attitude has become an essential part of financial literacy (Muaddab, 2015). The majority of students have performed a positive financial attitude. Results of the independent T-test show a significant difference between students from low and highgrade schools. High-grade school students recorded a better financial attitude compare to low-grade school students. High-grade school students tend to spend money wisely, gathering information prior to make purchases, including the price and quality of the products. This is allegedly related to their financial knowledge, which was also recorded a better score. This finding is in line with Potrich (2016) that found a significant positive correlation between financial knowledge and behavior. The individual with a high level of financial knowledge is more likely to have a better financial attitude.

Financial education in school tend to focus more on knowledge aspect but less on attitude aspects (Amagir et al., 2017). Therefore, a positive financial attitude was found in students from science majors from both schools. Students taking science majors in highgrade schools tend to save more and spend money wisely. While students taking science in low-grade school tend to not look at money as a source of power and prestige, also have better self-control from buying stuff when they do not have enough money. Meanwhile, pocket money was found to be negatively significant related to financial knowledge. This is contrary with previous studies that found an individual with the greater amount of pocket money tend to have a higher level of financial knowledge (Moon, Ohk \& Choi 2014), where an increase in pocket money is believed to raise the chance to expose with more financial activities, and this has appeared as a positive factor that influences the level of financial knowledge.

The self-control of students was classified as the low category, with an average score of 44.76. As adolescents, high school students tend to be emotionally unstable so that some of them feel more difficult to control themselves (Weaver, Moschis, \& Davis, 2011). Other than that, Baumeister (2002) states that failure in controlling themselves can be caused by having no goals related to financial activities. This study found a significant difference in terms of self-control of students based on school passing grade score. Students from the low-grade school have better self-control rather than those from highgrade school. Low-grade school students found it was quite easy for them to break the bad habits, they tend to avoid the laziness, and able to resist temptation, they also tend to have less problem with concentrating. Meanwhile, students of social majors have greater ability in self-controlling compare to students of science majors. They recorded to have less problem in concentrating, more diligent, able to resist temptation, and good at keeping secrets. The correlation test shows similar results. Major of course and school passing grade score is positively related to self-control. Greater ability in self-controlling is shown in students taking social major and students of the low-grade school. These results are contrary to the research hypothesis where students of the high- grade school, with a higher level of cognitive ability, are predicted to control themselves better, in lines with Luhrmann et al. (2014) and Calero, Garcia-Martin, Jimenez, \& Kazen (2007). CobbClark, Dahmann, and Kamhöfe (2019) state that individuals with greater ability in selfcontrolling tend to be consistent with long-term goals, financial goals included. Gender has a negative correlation with the self-control variable. Male students are able to control themselves better than female students. Self-control itself has a positive and significant correlation and effects on financial behavior. 
In this study, financial behavior consists of saving and spending behavior. The financial behavior of students was categorized as poor. This may be caused by poor selfcontrol. Low level of self-control ability will increase the chance of individual to risky financial behavior (Efendi, Indartono, Sukidjo, 2019; Fenton-O'Creevy, Dibb, \& Furnham, 2018; Weaver, Moschis, \& Davis, 2011). Pocket money is found to have no effects on financial behavior. This results in lines with a study conducted by Faidah et al., (2018). Faidah et al. argued that this might happen to the fact that income is not only for savings but also to be used to fulfill other needs such as consumption. Thus, increasing the amount of income will increase not only the savings but also consumption.

The limitation of this study includes the sample selection that was not used a random sampling technique due to restriction from school. In addition, the study did not examine other external factors, such as financial socialization by parents and peer groups.

\section{Conclusion and Recommendations}

\section{Conclusion}

The financial knowledge of students was on a moderate level. High-grade school students tend to have a better financial attitude than low-grade school students. The results of this study show that self-control of students is classified as low level with an average score of 44.76. Financial behavior, which consists of saving and spending behavior, were categorized as poor. There was a significant difference in financial knowledge, financial attitude, and self-control among both schools. The financial attitude was positively significantly related to financial knowledge and behavior. Self- control was associated positively with financial behavior. The results of the regression test revealed a significant positive effect of financial attitude and self-control towards financial behavior. In comparison, financial knowledge had no impact on financial behavior at the level of significant 0.05 .

\section{Recommendation}

Based on research results, it is recommended that the government improve the subjects related to financial education through more focus on attitudes and behavioral aspects. High school students may have a deeper understanding of various financial concepts such as time value of money and compound interest rate. Other than that, subjects that emphasize the benefits of financial literacy for the future is important so that students will implement it in everyday life. For future research, it is suggested to include more factors as a predictor of financial behavior, such as motivation, lifestyle, and financial socialization from parents and peer groups.

\section{References}

Amagir, A., Groot, W., Brink, H.M., \& Wilchut, A. (2017). Financial literacy of high school students in netherland: knowledge, attitudes, self-efficacy, and behavior. Tier Working Paper Series.

Ardiana, M. (2016). Self-control, family financial management education, knowledge of student financial inclusion have an effect on the saving behavior of vocational 
school students in Kediri. Journal of Educational Economics and Entrepreneurship, 4(1), 59-75. DOI: 10.26740/jepk.v4n1.p59-75

Atkinson, A., \& Messy, F. A. (2012). Measuring financial literacy: results of the oecd / international network on financial education (infe) pilot study. OECD Working Papers on Finance, Insurance and Private Pensions. Paris: OECD Publishing

Baumeister, R. F. (2002). Yielding to temptation: self -control failure, impulsive purchasing, and consumer behavior. Journal of Consumer Research, 28(4), 670676. https://doi.org/10.1086/338209

Calero, M. D., Garcia-Martin, M. B., Jimenez, M. I., \& Kazen, M. (2007). Self- regulation advantage for high-IQ children: Findings from a research study. Learning and Individual Differences, 17(4), 328-343. DOI:10.1016/j.lindif.2007.03.012

Chen, H., \& Volpe, R. P. (1998). An analysis of personal financial literacy among college students. Financial Services Review, 7(2), 107-128. https://doi.org/10.1016/S1057-0810(99)80006-7

Cobb-Clark, D. A., Dahmann, S. C., Kamhöfe, D. A., \& Schildberg-Hörisch, H. (2019). Self-Control: Determinants, Life Outcomes and Intergenerational Implications. Bonn, Germany: IZA Institute of Labor Economics. Retrieved from https://papers.ssrn.com/sol3/papers.cfm?abstract_id=3427627

Efendi, R., Indartono, S., \& Sukidjo. (2019). The mediation of economic literacy on the effect of self control on impulsive buying behaviour moderated by peers. International Journal of Economics and Financial Issues, 9(3), 98-104. https://doi.org/10.32479/ijefi.7738

Faidah, N., Harti., \& Subroto, W. T. (2018). The influence of economic experience, selfcontrol and student income on the economic behavior of high school students in Pasir Belengkong District, Paser Regency. Journal of Educational Economics and Entrepreneurship, 6(1), 59-82. Retrieved from https://journal.unesa.ac.id/index.php/jepk

Farhatilwardah, Hastuti, D., \& Krisnatuti, D. (2019). Adolescent courtesy characters: influence of parental socialization methods and self-control. Journal of Family and Consumer Science, 12(2), 114 - 125. DOI:10.24156/jikk.2019.12.2.114

Fenton-O'Creevy, M., Dibb, S., \& Furnham, A. (2018). Antecedents and consequences of chronic impulsive buying: Can impulsive buying be understood as dysfunctional self-regulation? Psychology and Marketing, 35(3), 175-188. DOI: 10.1002/mar.21078

Fitriani, N., Widodo, P. B., \& Fauziah, N. (2013). The relationship between conformity and consumptive behavior in students in Genuk Indah Semarang. Undip Psychology Journal, 55-68. DOI: 10.14710/jpu.12.1.1-14

Gaurav, S., \& Singh, A. (2012). An inquiry into the financial literacy and cognitive ability of farmers: evidence from rural india. Oxford Development Studies, 40(3), 358380. DOI: 10.1080/13600818.2012.703319

Hastings, J. S., Madrian, B. C., \& Skimmyhorn, W. L. (2013). Financial literacy, financial education, economy outcome. The Annual Review of Economics, 5, 347-373. DOI:10.1146/annurev-economics-082312-125807

Huston, S. J. (2010). Measuring financial literacy. Journal of Consumer Affairs, 44(2), 296-316. DOI: 10.1111/j.1745-6606.2010.01170.x

Kanserina, D. (2015). The effect of economic literacy and lifestyle on the consumer behavior of students majoring in economic education, Undiksha 2015. Journal 
of Economic Education, 5(1). Retrieved from https://ejournal.undiksha.ac.id/index.php/JJPE/article/view/5213

Kim, J., \& Chatterjee, S. (2013). Childhood financial socialization and young adults' financial management. Journal of Financial Counseling and Planning, 24(1), 61$79 . \quad$ Retrieved from https://www.afcpe.org/wpcontent/uploads/2018/10/v24_1_61-79.pdf

Laily, N. (2013). The effect of financial literacy on student behavior in managing finances. Journal of Accounting and Business Education, 1(4). DOI: 10.26675/jabe.v1i4.6042

Lührmann, M., Serra-Garcia, M., \& Winter, J. (2014). Teaching teenagers in finance: does it work? Journal of Banking \& Finance, 54, 160174.DOI:10.1016/j.jbankfin.2014.11.009

Lusardi , A. M., Mitchell , O. S., \& Curto, V. (2009). Financial literacy among the young. Journal of consumer affairs, 44(2), 358-380. DOI: 10.1111/j.17456606.2010.01173.x

Mahdzan, N.S., \& Tabiani, S. (2013). The impact of financial literacy on individual saving: an exploratory study in malaysia context. Transformation in Business and Economics, 12(1), 41-55. Retrieved from https://www.researchgate.net/profile/Nurul_Mahdzan/publication/275056695_T he_Impact_of_Financial_Literacy_on_Individual_Saving_An_Exploratory_Stud y_in_the_Malaysian_Context/links/553202fd0cf27acb0deaaff9.pdf

Mandell, L. (2008). Financial literacy of high school students. In Xiao, J.J (Eds). Handbook of Consumer Finance Research (pp. 69-81). New York: Springer https://doi.org/10.1007/978-0-387-75734-6_5

Moon, C. S., Ohk, K., \& Choi, C. (2014). Gender differences in financial literacy among chinese university students and the influential factors. Asian Women, 30(2), asianwomen.org/xml/02242/02242.pdf

$$
\text { 3-25. Retrieved from http://e- }
$$

Muaddab, H. (2015). Factors that influence green consumption behavior in students of SMK Negeri, Jombang Regency. Journal of Education and Teaching Sciences, 2(2), 126-145. DOI: https://doi.org/10.17509/edusentris.v2i2.166

[OECD] Organisation for Economic Cooperation and Development. (2017). PISA 2015 Result (Volume IV): Students' Financial Literacy. Paris: OECD Publishing

[OJK] Otoritas Jasa Keuangan. 2016. Survei Nasional Literasi dan Inklusi Keuangan 2016. Retrieved from www.ojk.go.id.

Opoku, A. (2015). Financial literacy among senior high school students: evidence in Ghana (Master Thesis). Retrieved from http://ir.knust.edu.gh/bitstream/123456789/8511/1/ARMSTRONG\%20OPOKU. pdf

Otto, P. E., Davies, G. B., \& Chater, N. (2007). Note on ways of saving: mental mechanisms as tools for self-control? Global Business and Economic Review, 9(2), 227-254. DOI: 10.1504/GBER.2007.013703

[PRI] Policy Research Initiative. (2005). Why Financial Capability Matters. Synthesis Report, Prepared by Social and Enterprise Development Innovations for the PRI Project "New Approaches for Addressing Poverty and Exclusion". Report on "Canadians and Their Money: A National Symposium on Financial Capability". Ottawa, June 9-10, 2005 in Ottawa. Retrieved from https://www.canada.ca/content/dam/canada/financial-consumer- 
agency/migration/eng/resources/researchsurveys/documents/sedifcac_fincapability-eng.pdf

Potrich A.C.G, Mendes-da-silva W., \& Vieira K.M. (2016). Development of a financial literacy model for university students", Management Research Review, 39(3), 356-376. DOI: 10.1108/MRR-06-2014-0143

Rajha, A. (2011). Knowledge, attitude, practice and satisfaction on personal financial management among the medical practitioners in the public and private medical services in Malaysia (Master Thesis). Retrieved from https://www.researchgate.net/profile/Anthony_Rajna/publication

Setiawati., \& Nurkhin, A. (2017). Testing the dimensions of the student financial literacy construct. Economic Education Analysis Journal, 3(1), 727-736. Retrieved from https://journal.unnes.ac.id/sju/index.php/eeaj/article/view/20283

Shim, S., Barber, B. L., \& Card, N. A. (2010). Financial socialization of first-year college students: the roles of parents, work, and education. Journal Youth Adolescence, 39, 1457-1470. DOI: $10.1007 / \mathrm{s} 10964-009-9432-\mathrm{x}$

Sinaga, R. F. (2017). Analysis of the dominant factors influencing the selection of private schools for SMA level in Medan City. Jurnal Suluh Pendidikan FKIP- UHN, 4(1), 77-86. Retrieved from http://jsp.uhn.ac.id/wpcontent/uploads/2018/03/09_Jurnal-Rani.pdf

Tangney, J. P., Baumeister, R. F., \& Boone, A. L. (2004). High Self-Control Predicts Good Adjustment, Less Pathology, Better Grades, and Interpersonal Success. Journal of Personality, 72(2), 271-322. DOI: 10.1111/j.0022- 3506.2004.00263.x

[UNICEF] United Nations Children's Fund. (2011). Adolescence: An Age of Opportunity. New York: UNICEF

Weaver, S. T., Moschis, G. P., \& Davis, T. (2011). Antecedents of materialism and compulsive buying: A life course study in Australia. Australian Marketing Journal, 19(4), 247-256. https://doi.org/10.1016/j.ausmj.2011.04.007

Xiao, J. J. (2008). Applying behavior theories to financial behavior. In Xiao, J.J (Eds). Handbook of Consumer Finance Research (pp. 69-81). New York: Springer https://doi.org/10.1007/978-0-387-75734-6_5

Xiao, J. J., Chatterjee, S., \& Kim, J. (2014). Factors associated with financial independence of young adults. International Journal of Consumer Studies, 38, 394-403. DOI:10.1111/ijcs.12106

Yeboah, A. P., Frejus, W. B., \& Fianko, E. (2018). Financial literacy of undergraduate students: do personality traits and cognitive ability matter? International Journal of Accounting and Financial Reporting, 8(4), 533-554. DOI: 10.5296/ijafr.v8i4. 14012

Zahirovic-Herbert, V., Gibler, K. M., Chatterjee, S.(2016). Financial literacy, risky mortgages, and delinquency in the US during the financial crisis. International Journal of Housing Markets and Analysis, 9(2), 164-189. DOI: 10.1108/IJHMA12-2014-0060 